\title{
Ocorrência de Graphiola phoenicis em tamareira no Maranhão
}

\author{
Tathianne Pastana de Sousa Poltronieri ${ }^{1}$; Jaqueline Rosemeire Verzignassi ${ }^{2}$; Ruth Linda Benchimoli3; Luiz Sebastião \\ Poltronieri³; Eudes de Arruda Carvalho ${ }^{3}$
}

\begin{abstract}
${ }^{1}$ Departamento de Fitopatologia e Entomologia, Instituto de Biologia, Universidade Federal Rural do Rio de Janeiro, CEP 23890-000, Rio de Janeiro, RJ. ${ }^{2}$ Embrapa Gado de Corte, Avenida Rádio Maia, 830, CEP 79106-550, Campo Grande, MS. ${ }^{3}$ Embrapa Amazônia Oriental, Tv. Enéas Pinheiro, S/N, CEP 66095-100, Belém, PA.

Autor para correspondência: Jaqueline Rosemeire Verzignassi (jaqueline@cnpgc.embrapa.br)

Data de chegada: 12/03/2012. Aceito para publicação em: 01/08/2012.
\end{abstract}

A tamareira ou datileira (Phoenix dactylifera L.) é uma palmeira extensivamente cultivada pelos seus frutos comestíveis, as tâmaras. Com origem na Ásia e na China, essa planta apresenta extrema importância em quase todas as regiões desérticas. Ricas em ácido pantotênico (vitamina B5), são conhecidas pelo seu efeito tranquilizante. Muitas vezes são chamadas de "doses naturais de anti-estressante" pela capacidade que tem de relaxar e proporcionar sensação de bemestar. Plantas de tamareira, provenientes do Maranhão, com sintomas iniciais que caracterizavam-se por numerosas manchas amareladas nos dois lados do folíolo e na ráquis, foram analisadas no Laboratório de Fitopatologia da Embrapa Amazônia Oriental. As manchas nas folhas coalesciam e delas emergiam os soros, que são as estruturas reprodutivas do fungo, as quais se assemelhavam, quando vistas a olho nu, a restos de carapaças ou fezes deixadas por insetos (Figura 1-A). O material foi mantido em câmara úmida e, após três dias, observou-se, por microscopia óptica, exsudação de esporos amarelos pulverulentos, intercalados com feixes de hifas, emergindo do interior dos soros. As hifas estendiam-se por cerca de
1 a $2 \mathrm{~mm}$ para fora dos soros (Figura 1-B e 1-C). De acordo com as características (Figura 1) e, com auxílio de literatura especializada, o fungo foi identificado como Graphiola phoenicis (Moug.) Poit., sinonímia Phacidium phoenicis Moug. Ex Fr. (DJERBI, M. Diseases of the palm (Phoenix dactylifera). Regional Project for Palm \& Dates Research Centre in the Near East \& North África. Baghdad, Iraq: FAO. 1983; SIMONE, G.W. Graphiola leaf spot (false smut). In: M. L. Elliot; T.K. Broschat (Eds.). Diseases and disorders of ornamental palms. Minnesota: American Phytopathological Society, 1993. p. 14-16). O fungo é da classe dos basidiomicetos e causador da doença conhecida como mancha foliar de grafiola ou falso carvão. A alta umidade do ambiente constitui fator preponderante para o desenvolvimento do fungo. Infecções severas deste fungo podem provocar a redução do crescimento da planta e da produção de frutos, levando à morte prematura dos tecidos foliares. No Brasil, o patógeno foi encontrado em Pernambuco, Espírito Santo e São Paulo. Este é o primeiro relato de Graphiola phoenicis em tamareira no Maranhão.

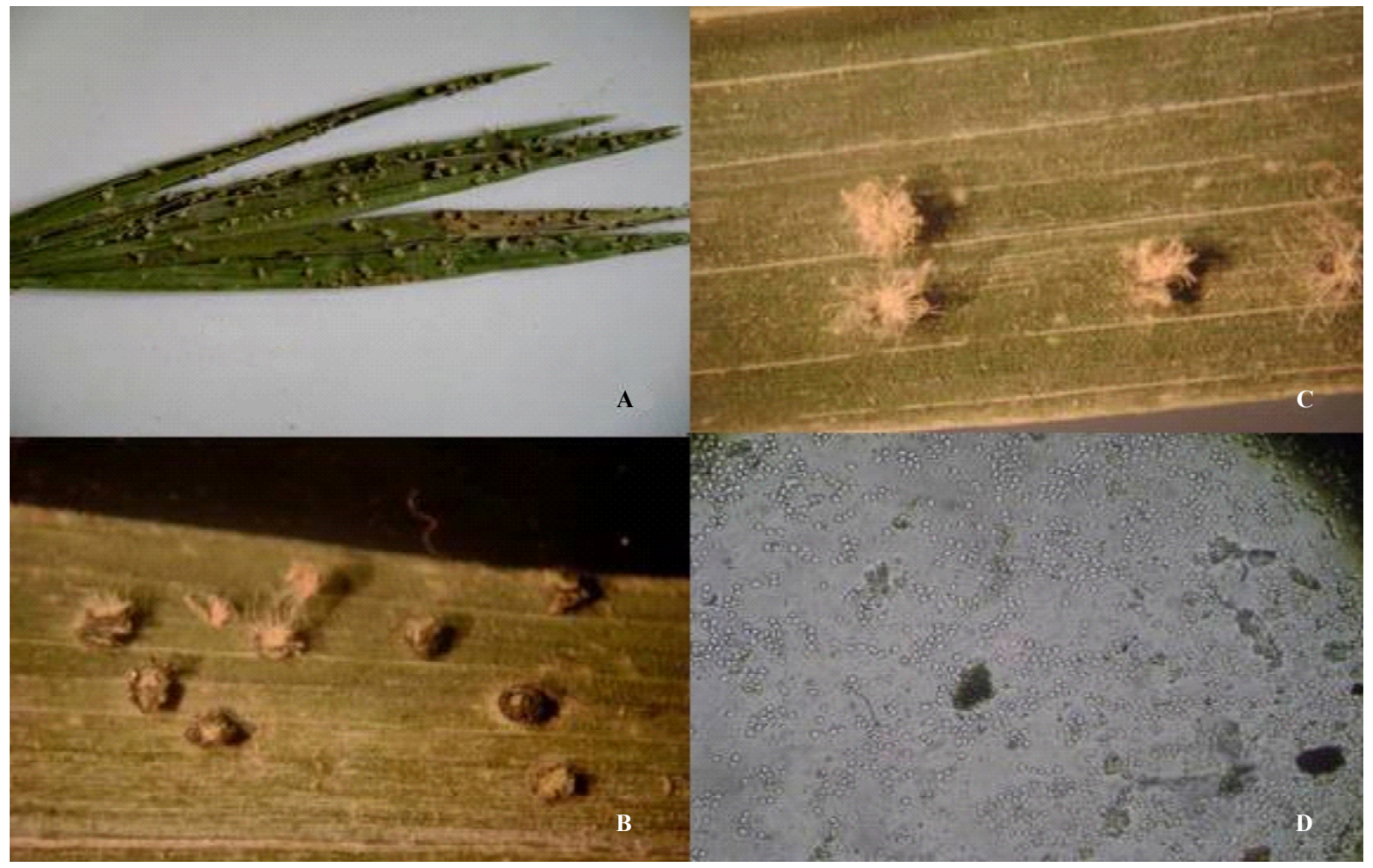

Figura 1. Folíolos de tamareira apresentando sintomas de mancha foliar de Graphiola phoenicis (A); detalhes dos soros (B e C); conídios do fungo (D). 